\title{
Effect of Phaleria macrocarpa (Scheff.) Boerl Dry Extract to the Level of Malondialdehyde
}

\author{
Meiyanti, ${ }^{1}$ Eveline Margo, ${ }^{2}$ Juni Chudri ${ }^{2}$ \\ ${ }^{1}$ Department of Pharmacology and Medical Pharmacy, Faculty of Medicine, Universitas Trisakti, Jakarta, \\ Indonesia, ${ }^{2}$ Department of Physiology, Faculty of Medicine, Universitas Trisakti, Jakarta, Indonesia
}

\begin{abstract}
Increased age causes an increase in degenerative diseases. Antioxidants in the body unable to neutralize the increased concentration of free radicals. The flesh of the Phaleria macrocarpa (Scheff.) Boerl contains flavonoids which have antioxidant effects. At present, there are still very limited clinical trials of Phaleria macrocarpa (Scheff.) Boerl. This study was an experimental pretest and posttest involving 30 healthy volunteers receiving glucose loads in November 2018-February 2019 in Jakarta. This study aimed to assess the antioxidant effect of Phaleria macrocarpa (Scheff.) Boerl dry fruit extract in various dosage ranges. Subjects of this study aged 30-55 years. The data collection included anthropometric examination and malondialdehyde levels before and after administration of dry fruit extract doses of $62.5 \mathrm{mg}, 125 \mathrm{mg}$, and $250 \mathrm{mg}$ at 150 minutes after oral glucose induction. Data analysis using a paired t test with $\mathrm{p}<0.05$. Decreased levels of malondialdehyde in the administration of Phaleria macrocarpa (Scheff.) Boerl with a dose of $62.5 \mathrm{mg}, 125 \mathrm{mg}$, and $250 \mathrm{mg}$ by $40.9 \%, 22.9 \%$, and $18.3 \%$ compared to the baseline malondialdehyde level $(1,608 \mathrm{nmol} / \mathrm{mL})$. Statistical analysis using a paired $\mathrm{t}$ test showed $\mathrm{p}=0.000$ for all three doses compared with baseline levels. Dry fruit extract of Phaleria macrocarpa (Scheff.) Boerl has an antioxidant effect; the antioxidant effect of the extract is not directly proportional to the dose.
\end{abstract}

Key words: Extract, malondialdehyde, Phaleria macrocarpa

\section{Efek Antioksidan Ekstrak Kering Phaleria macrocarpa (Scheff.) Boerl terhadap Kadar Malondialdehid}

\begin{abstract}
Abstrak
Pertambahan usia menyebabkan peningkatan penyakit degeneratif. Antioksidan dalam tubuh tidak mampu menetralkan peningkatan konsentrasi radikal bebas. Daging buah Phaleria macrocarpa (Scheff.) Boerl mengandung flavonoid mempunyai efek antioksidan. Saat ini masih sangat terbatas uji klinis Phaleria macrocarpa (Scheff.) Boerl. Penelitian ini merupakan uji eksperimental sebelum dan sesudah perlakuan pada 30 sukarelawan sehat yang diinduksi dengan glukosa yang dilaksanakan pada bulan November 2018-Februari 2019 di Jakarta. Penelitian ini bertujuan menilai efek antioksidan ekstrak kering buah Phaleria macrocarpa (Scheff.) Boerl dalam beberapa kisaran dosis yang diberikan. Subjek penelitian berusia 30-55 tahun. Pengumpulan data meliputi pemeriksaan antropometri serta kadar malondialdehid sebelum dan sesudah pemberian ekstrak kering dosis 62,5 mg, $125 \mathrm{mg}$, dan $250 \mathrm{mg}$ pada menit 150 setelah dilakukan induksi glukosa oral. Analisis data menggunakan uji t berpasangan dengan $\mathrm{p}<0,05$. Penurunan kadar malondialdehid pada pemberian ekstrak Phaleria macrocarpa (Scheff.) Boerl dosis 62,5 mg, $125 \mathrm{mg}$, dan $250 \mathrm{mg}$ sebesar 40,9\%, 22,9\%, dan 18,3\% dibanding dengan kadar malondialdehid sebelum pemberian $(1.608 \mathrm{nmol} / \mathrm{mL}$ ). Analisis statistik menggunakan uji t berpasangan didapatkan $\mathrm{p}=0,000$ untuk ketiga dosis dibanding dengan kadar awal. Ekstrak kering buah Phaleria macrocarpa (Scheff.) Boerl mempunyai efek antioksidan; efek antioksidan ekstrak tidak berbanding lurus dengan dosis.
\end{abstract}

Kata kunci: Ekstrak, malondialdehid, Phaleria macrocarpa 


\section{Introduction}

At present, the development of medical science is so rapid that it raises an increase in one's life expectancy. Life expectancy is the leading indicator of a person's health quality. ${ }^{1}$ In 1999 life expectancy in Indonesia was 66.2 years. In 2007 , it increased to 70 years, and in 2014, it became 71 years, ${ }^{1,2}$ causing an increase in risk for various degenerative diseases. Degenerative diseases found in many communities are cancer, heart disease, diabetes, arthritis, liver disease, and others.

These degenerative diseases caused the inability of antioxidants in the body to neutralize the increase in free radical concentration. Free radicals are molecules that in their outer orbit have one or more unpaired electrons; they are very labile and very reactive so that they can cause damage to the cell components. An example is superoxide formed from hydroxyl radical, which initiates lipid peroxidation. The compound causes damage to the endothelial plasma membrane, lipoproteins, and deoxyribonucleic acid (DNA) genetic carrier. Hydrogen peroxide causes oxidative stress, one of which can be measured by using malondialdehyde (MDA). Lipid peroxidation can be detected indirectly by measuring plasma hydrolysis of lipoperoxidase to MDA form. ${ }^{3,4}$

One of the degenerative diseases, diabetes mellitus (DM), is currently a worldwide health problem. In 2011 around 366 million adults suffered from DM. It estimated that in 2030 there would a substantial increase of up to 551 millions patients with DM. ${ }^{5}$ The condition of hyperglycemia results in an increase in oxidative stress, where it results from an imbalance between the formation of free radicals and antioxidants, which is an essential factor in the occurrence of blood vessel disorders. Previous clinical studies report that oxidative stress plays a significant role in the pathogenesis and development of complications of DM.3.,4,6

One of the medicinal plants that are known to have antioxidant effects and widely used in the community is Phaleria macrocarpa (Scheff.) Boerl (PM). Some laboratory analysis studies show that PM showed an antioxidant effect, especially in young fruit and leaves. ${ }^{7,8}$ Currently, scarce clinical trials are conducted to prove the antioxidant effects of PM. This study aims to assess the antioxidant effects of dried fruit pulp extract PM in a range of doses. It is necessary to determine the antioxidant effects of dried extract and the range of doses that provide the best antioxidant effect.

\section{Methods}

Respondents of this study were 30 healthy adult volunteers who fulfilled the following inclusion criteria. The criteria were men and women aged 30-55 years, having a healthy body weight (body mass index $18.5^{-25} \mathrm{~kg} / \mathrm{m}^{2}$ ). They are not having chronic diseases and no history of chronic diseases in the family, especially diabetes mellitus, hypertension, heart disease, supported by laboratory tests showing routine blood tests, liver function (SGPT, alkaline phosphatase), and normal kidney function (creatinine levels). They also have not consumed herbs or vitamin supplements a week before the study takes place/ during the study. Subjects in the previous 24 hours do not consume drinks containing caffeine, fruit juice, or smoking, and willing to take part in research and sign an informed consent. Exclusion criteria were pregnant or breastfeeding, consumed other drugs for the previous a week, or during the study that can affect blood glucose levels such as corticosteroid drugs, and participating in other studies within three months before this study.

The PM pericarp (without seed coat and seed) obtained from plant nurseries in the region of Semarang, Central Java. At each visit, subjects were given a glucose load of 400 calories (or 75 grams of glucose). The first visit only glucose load is given, whereas, in the second visit, $62.5 \mathrm{mg}$ PME was given. They wash out for one week, and, at the next visit, subjects consumed $125 \mathrm{mg}$, and the following week consumed $250 \mathrm{mg}$ PME. The parameters used to measure MDA levels.

Antioxidant effects were assessed by measuring MDA levels by determining MDA levels in serum after reacting with thiobarbituric acid (TBA) at hot temperatures in an acidic atmosphere. This reaction produces a red solution, which then measured using a spectrophotometer. The reagents used are the MDA standard, trichloroacetic acid (TCA), and TBA. Before the research took place, accuracy and precision test of the MDA examination carried out. This research has passed the ethical review of the Research Ethics Committee of Faculty of Medicine of Universitas Trisakti with letter number: 137/ KER/FK/I/2019. 


\section{Results}

A total of 40 subjects examined for anthropometry (body weight and height) and body mass index examination. Besides, laboratory tests (hematology, blood sugar, SGPT, and creatinine) also carried out. Of the 40 subjects examined, only 30 people met the inclusion and exclusion criteria. Of the 30 volunteer subjects, 16 were women, and 14 were men. Personal data from 30 subjects are in Table 1.

In this study, the average age of subjects was 41.4 years, body weight in the range of $40-70$ kilograms, height was $143-174 \mathrm{~cm}$, and body mass index was $18.66-24.84 \mathrm{~kg} / \mathrm{m}^{2}$.

This study used auto control to monitor subjects. At the beginning of the study, all subjects tested for oral glucose tolerance with 75 grams of glucose and blood samples taken in 150 minutes after glucose induction as the baseline measure. After a week washout, subjects consumed glucose induction and PME at a dose of $62.5 \mathrm{mg}, 125 \mathrm{mg}$, and $250 \mathrm{mg}$, respectively. The washout is performed one week before treatment with different doses. MDA was at 150 minutes after glucose induction. The results of the average examination of MDA levels in the $150^{\text {th }}$ minute are in Table 2.

Table 3 shows the results of the statistical analysis of baseline MDA levels with PME doses

Table 1 Characteristics of the Subject

\begin{tabular}{lc}
\hline Characteristics & $\begin{array}{c}\text { Mean } \pm \text { SD } \\
\mathbf{n}=\mathbf{3 0}\end{array}$ \\
\hline Age (years) & $41.40 \pm 6.41$ \\
Sex & \\
Female & 16 \\
Male & 14 \\
Weight $(\mathrm{kg})$ & $56.05 \pm 7.68$ \\
Height $(\mathrm{m})$ & $1.58 \pm 0.09$ \\
Body mass index $\left(\mathrm{kg} / \mathrm{m}^{2}\right)$ & $22.29 \pm 2.04$ \\
\hline
\end{tabular}

Table 2 Baseline MDA and PME Level

\begin{tabular}{lc}
\hline PME Doses & $\begin{array}{c}\text { MDA Level } \\
\text { (Average } \pm \text { SD) }\end{array}$ \\
\hline Baseline & $1.608 \pm 0.509$ \\
PME 62.5 mg & $0.950 \pm 0.215$ \\
PME $125 \mathrm{mg}$ & $1.239 \pm 0.230$ \\
PME 250 mg & $1.313 \pm 0.323$ \\
\hline
\end{tabular}

Table 3 Effect PME on Level MDA

\begin{tabular}{lc}
\hline Variables & $\begin{array}{c}\text { p } \\
\text { Value }^{*}\end{array}$ \\
\hline MDA baseline vs MDA PME 62.5 mg & 0.000 \\
MDA baseline vs MDA PME 125 mg & 0.000 \\
MDA baseline vs MDA PME 250 mg & 0.000 \\
\hline Note: "Paired t test, p<0.05 significant difference &
\end{tabular}

Note: "Paired t test, $\mathrm{p}<0.05$ significant difference

of $62.5 \mathrm{mg}, 125 \mathrm{mg}$, and $250 \mathrm{mg}$. From the results, there is a significant difference $(\mathrm{p}<0.05)$ between the two groups.

From Figure 1, it is seen that the MDA level decreases on a fairly large scale compared to the baseline at the PME dose of $62.5 \mathrm{mg}$, while the PME dose of $125 \mathrm{mg}$ and $250 \mathrm{mg}$ shows a decrease in MDA levels but not too large compared to the $62.5 \mathrm{mg}$ dose.

\section{Discussion}

In this study, 30 volunteered with an average age of 41.4 years to show the antioxidant effect of PME. Age or aging associated with free radicals. Aging is a biological process that cannot be avoided and is related to biochemical and physiological changes that are gradual and spontaneous and increase the body's susceptibility to disease. Scientific studies have shown that the aging process causes a decrease in the body's ability to use calories from food, decrease hormone function, suppress enzyme function, and decrease the body's

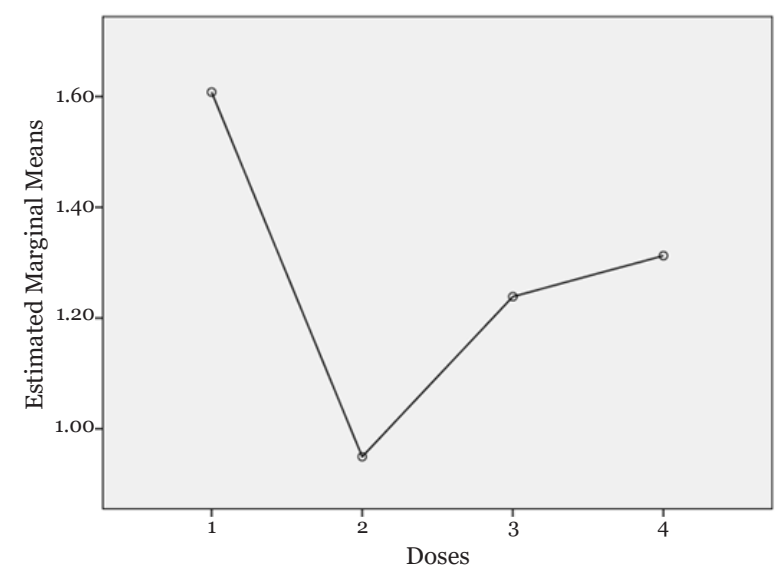

Figure The Effect of PME on MDA Level (nmol/mL) of Subject Baseline (1), and PME Dose 62.5 mg (2), $125 \mathrm{mg}$ (3), and $250 \mathrm{mg}$ (4) 
resistance to fight disease. Aging results from an accumulation of changes caused by reactions in the body that are started by high reactive molecules known as 'free radicals.' These changes produce free radicals believed to be a significant cause of the aging process. ${ }^{1,3}$

Free radicals define as an atom, molecule, or component that contains unpaired electrons, so that it is generally unstable, has a short life, and is very reactive. The free radicals produced due to the use of oxygen in the metabolic process. These free radicals are produced by healthy body cells through metabolic processes, and also by external sources such as carcinogenic compounds and ionizing radiation. ${ }^{3,9}$

Free radicals produced from the results of the body's metabolism. They also caused by external factors such as cigarette smoke, the results of ultraviolet irradiation, organic trigger substances in foods, and other pollutants. Disease caused by free radicals is chronic. It will take years to become apparent or show any symptoms. Examples of diseases that are often associated with free radicals are heart attacks, cancer, cataracts, and decreased kidney function. To prevent or reduce chronic disease because free radicals are needed antioxidants. The human body can neutralize these free radicals; only if the amount is excessive, the ability to neutralize it will decrease. ${ }^{10,11}$

Research on the chemical content of eggshell seeds and fruit flesh PM showed that in hexane, ethyl acetate and methanol extract flavonoids, phenols, tannins, saponins, and sterols/terpenes with the highest content is saponins..$^{12-14}$

The four main parts of MD plants that often used in society are the stems, leaves, seed shells, and fruit flesh. ${ }^{8,15}$ Research on the chemical content of seeds and fruit flesh obtained alkaloid compounds, saponins, flavonoids, and polyphenols. Besides having the antioxidant effect of flavonoid content, the use of PME in DM cases can increase insulin expenditure by changing the metabolism of $\mathrm{Ca}^{2+}$ and can regenerate the island of Langerhans, especially $\beta$ cells. Flavonoid contained in MD as an antioxidant that will protect pancreatic cell damage from free radicals. ${ }^{16,17}$

Flavanoids are a natural antioxidant and have biological activities, including antioxidants that can inhibit various oxidation reactions and can act as reducing hydroxyl radicals, superoxide, and peroxyl radicals. Extract the ethanol of young PM fruits has an inhibitory power of $78.48 \%$, and the old fruit has an $83.08 \%$ inhibitory effect, meaning that the old fruit PM has a higher antioxidant effect. ${ }^{11-14}$

This study used an oral glucose tolerance test procedure. In a hyperglycemic state, it will produce free radicals. The highest MDA levels were seen in 150 minutes after 45-gram glucose loading, such as a glucose tolerance test. MDA levels in the $150^{\text {th }}$ minute will be taken as a baseline (without the administration of PME), and MDA levels will be measured again at the same time (150 minutes) with extracts of 62.5 $\mathrm{mg}, 125 \mathrm{mg}$, and $250 \mathrm{mg}$.

This study is an advanced study of the utilization of PME as an anti-hypoglycemic and antioxidant drug in patients with DM. Diabetes characterized by a relative or absolute deficiency of insulin secretion and resistance. It causes chronic hyperglycemia and impaired carbohydrate, lipid, and protein metabolism. DM is known as an oxidative stress disorder that occurs due to an imbalance between the formation of free radicals and the natural antioxidant abilities of the body. Many studies have reported that oxidative stress plays a role in systemic inflammation, endothelial dysfunction, impaired pancreatic $\beta$ cell secretion, and impaired glucose utilization in peripheral tissues. $3,4,6$

This oxidative stress also plays a vital role in complications that occur in diabetic patients. Sources of oxidative stress in diabetes include enzymatic, non-enzymatic, and mitochondrial pathways. Many factors influence the increased oxidative stress in DM. The dominant factor is the auto-oxidation of glucose, which causes an increase in free radicals. Increased extracellular glucose levels will induce the dysregulation of reactive oxygen and nitrogen pathways. This situation will cause disruption of the vascular endothelium and the production of nitric oxide (NO). Superoxide, when joining NO on endothelial cells, will produce peroxynitrite, which is a cytotoxic antioxidant. ${ }^{18,19}$

This research can be done in humans because PM is relatively safe and has been used for generations in Indonesian society. PM extracted with water and ethanol to obtain active ingredients that are antioxidants. ${ }^{20,21}$ The volume of medicinal ingredients is less than that of PM meat powder, with a ratio of 1 gram of $P M$ powder equal to $250 \mathrm{mg}$ of dried extract of the god's crown (PME).

The MDA level decreases on a reasonably large 
scale compared to the baseline at the PME dose of $62.5 \mathrm{mg}$, while the PME dose of $125 \mathrm{mg}$ and 250 mg shows a decrease in MDA levels but not too large compared to the $62.5 \mathrm{mg}$ dose. MDA levels assessed at 150 minutes after glucose induction. The mean MDA baseline level was 1,608, and with a dose of $62.5 \mathrm{mg}$ PME, we found a decrease in MDA levels of $40.9 \%$ compared to the baseline. Giving a PME dose of $125 \mathrm{mg}$ and $250 \mathrm{mg}$ obtained a decrease in MDA levels of $22.9 \%$ and 18.3\% compared to MDA baseline levels.

PME antioxidant activity from phenolic components and flavonoids contained in PM fruit. ${ }^{22}$ Karimi et al. ${ }^{23}$ reported that the content of the fruit consisted mainly of flavonoids and kaempferol, myricetin, naringin, quercetin. Correlation of flavonoid content in PM fruit with antioxidant activity caused by the presence of 3-hydroxyl groups in heterocyclic rings. In contrast, additional hydroxyl or methoxyl groups at position 3.5, and 7 rings $\mathrm{A}$ and $\mathrm{C}$ appear to be of less importance. Highly active flavonoids have ring $\mathrm{B}$, which is occupied by $3^{\prime} 4^{\prime}$-dihydroxy and 3-OH groups. ${ }^{24,25}$

From the results of statistical analysis, using a paired $t$ test between baseline and MDA administration level after PME was given a significant difference $(\mathrm{p}<0.05)$.

Complaints found in the subject are nausea and fullness on $250 \mathrm{mg}$ PME; this is probably due to the high saponin content in the PM fruit, which can cause gastrointestinal irritation. Besides, the effect of reducing blood pressure in subjects with $125 \mathrm{mg}$ or $250 \mathrm{mg}$ PME doses were apparent. This effect caused by the presence of PM fruit action mechanism such as ACE receptor inhibitors. ${ }^{25}$

The main limitation of this study is the design as a pre-post test experimental study without controls-further studies needed with the standards of a good clinical trial.

\section{Conclusion}

Dry fruit extract of Phaleria macrocarpa (Scheff.) Boerl has an antioxidant effect; the extract dose of $62.5 \mathrm{mg}$ has an antioxidant effect better than other doses. The antioxidant effect of the extract is not directly proportional to the dose.

\section{Conflict of Interest}

The authors do not have any conflict of interest to declare.

\section{Acknowledgments}

The researchers thank the Faculty of Medicine of Universitas Trisakti and Research Institution (Lembaga Penelitian) of Universitas Trisakti for funding this study. Thanks are also due to the Dhammasavana Foundation, and all subjects participate in this study.

\section{References}

1. Pangkahila W. Anti-aging: tetap muda dan sehat. Jakarta: Penerbit Buku Kompas; 2011.

2. Muziburrahman. Usia harapan hidup Indonesia [Internet]. 2014 August 23 [cited 2019 April 28]. Available from: http://zibur.blogspot.com/2014/o8/usia-harapanhidup-indonesia.html.

3. Zishan M, Ahmad Z, Idris S, Parveen Z, Hussain MW. Diabetes mellitus: role of free radicals and oxidative stress. World $\mathrm{J}$ Pharm Pharm Sci. 2017;6(5):448-70.

4. Sheikhpour R. Diabetes and oxidative stress: the mechanism and action. Iran J Diabetes Obes. 2013;5(1):40-5.

5. International Diabetes Federation. Global diabetes plan 2011-2021. Last update: 2017 August 1 [cited 2019 April 28]. Available from: https://www.idf.org/our-activities/ advocacy-awareness/resources-andtools/129-global-diabetes-plan-2011-2021. html.

6. Matough FA, Budin SB, Hamid ZA, Alwahaibi $\mathrm{N}$, Mohamed J. The role of oxidative stress and antioxidants in diabetic complications. Sultan Qaboos Univ Med J. 2012;12(1):5-18.

7. Altaf R, Asmawi MZ, Dewa A, Sadikun A, Umar MI. Phytochemistry and medicinal properties of Phaleria macrocarpa (Scheff.) Boerl extracts. Pharmacogn Rev. 2013;7(13);73-80.

8. Alara OR, Olalera OA. A critical overview on the extraction of bioactive compounds from Phaleria macrocarpa (Thymelaceae). Nat Prod Chem Res. 2016;4(5);1000232.

9. Zatalia SR, Sanusi H. The role of antioxidants in the pathophysiology, complications, and management of diabetes mellitus. Acta Med Indones. 2013:45(2);141-7.

10. Kangralkar VA, Patil SD, Bandivadekar RM. Oxidative stress and diabetes: a review. Int $\mathrm{J}$ Pharm Appl. 2010;1(1):38-45.

11. Phaniendra A, Jestadi DB, Periyasamy L. 
Free radicals: properties, sources, targets, and their implication in various diseases. Indian J Clin Biochem. 2015;30(1):11-26.

12. Othman SNAM, Sarker SD, Nahar L, Basar $\mathrm{N}$. The ethnomedicinal, phytochemical and pharmacological properties of Phaleria macrocarpa (Scheff). Boerl. TANG. 2014;4(4):e22.

13. Alara OR, Alara JA, Olalere OA. Review on Phaleria macrocarpa pharmacological and phytochemical properties. Drug Des. 2016;5(3):1000134.

14. Ramdani ED, Marlupi UD, Sinambela $\mathrm{J}$, Tjandrawinata RR. Isolation and identification of compounds from Phaleria macrocarpa (Scheff.) Boerl fruit extract. Asian Pac J Trop Biomed. 2017;7(4):300-5.

15. Susilawati, Matsjeh S, Pramono HD, Anwar C. Antioxidant activity of 2,6,4'- trihydroxy4-methoxy benzophenone from ethyl acetate extract of leaves of mahkota dewa (Phaleria macrocarpa (Scheff.) Boerl.). Indo J Chem. 2011;11(2):180-5.

16. Yayah W, Hudaya T, Prasetyo S, Wangsa J. Pretreatment and optimization studies on the extraction of antioxidant components from Phaleria macrocarpa fruit. ASEAN Eng J Part B. 2016;5(1):46-60.

17. Chang CLT, Lin Y, Bartolome AP, Chen YC, Chiu SC, Yang WC. Herbal therapies for type 2 diabetes mellitus: chemistry, biology, and potential application of selected plants and compounds. Evid Based Complement Alternat Med. 2013;2013:378657.

18. Zatalia SR, Sanusi H. The role antioxidants in the pathophysiology, complications, and management of diabetes mellitus. Acta Med Indones. 2013;45(2):141-7.

19. Giacco F, Brownlee M. Oxidative stress and diabetic complications. Circ Res. 2010;107(9):1058-70.

20. Rahmi E, Wahyuni WT, Darusman LK, Suparto IH. Combination of ethanolic extract of a-glucosidase inhibitory activity of Phaleria macrocarpa (Scheff). Boerl. fruits and Annona muricata Linn. leaves. Trad Med J. 2016;21(1):63-8.

21. Hendra R, Haryani Y. Phaleria macrocarpa (Boerl.) Scheff fruit: a potential source of natural antioxidant. PCPR. 2018;3(1):1-4.

22. Yanti AR, Radji M, Mun'im A, Suyatna FD. Antioxidant effect of methanolic extract of Phaleria macrocarpa (Scheff.) Boerl in fructose 10\%-induced rats. Int $J$ PharmTech Res. 2015;8(9):41-7.

23. Karimi E, Oskoueian E, Hendra R, Jaafar HZE. Evaluation of Crocus sativus L. stigma phenolic and flavonoid compounds and its antioxidant activity. Molecules. 2010;15(9):6244-56.

24. Kefayati Z, Motamed SM, Shojaii A, Noori M, Ghods R. Antioxidant activity and phenolic and flavonoid contents of extract and subfractions of Euphorbia splendida Mobayen. Pharmacognosy Res. 2017;9(4):362-5.

25. Hendra R, Ahmas S, Sukari A, Shukor MY, Oskoueian E. Flavonoid analyses and antimicrobial activity of various parts of Phaleria macrocarpa (Scheff.) Boerl fruit. Int J Mol Sci. 2011;12(6):3422-31. 